\title{
ĆOPIĆEV HUMOR I IGRIVOST KAO ČITALAČKI PARAMETRI KOJI SU NADVLADALI VREME Edina Murtić, Umjetnost pripovijedanja Branka Ćopića, University Press, Sarajevo, 2016.
}

\author{
Branislava Vasić Rakočević \\ Internacionalni Univerzitet u Novom Pazaru, \\ Novi Pazar, Srbija \\ branislava.vasic-rakocevic@uninp.edu.rs
}

Pisac Branko Ćopić, i osporavan i hvaljen, od strane savremenika pa do dan danas nalazi se $\mathrm{u}$ istom procepu i predmet je stalnih diskusija počev od književne vrednosti do zastupljenosti u školskim programima na području bivše SFRJ. No, deo kanona ili ne, ne može se prenebregnuti činjenica da su, ako ništa drugo, Ćopić kao pisac za decu i njegova kultna dela, ostavili trag u odrastanju ogromnog broja dece s ovih prostora, te ostavljaju i dan danas bez obzira na činjenicu koliko je tematika neaktuelna ili je milje stran prosečnom savremenom detetu. Ono što njegov prosede čini specifičnim jeste pre svega autentičan vid humora i igrivosti, odnosno igre, koji su konstituenti u stvaranju jednog boljeg, bezbrižnijeg i prihvatljivijeg sveta. Igra je oznaka aktivizma, dostizanje mnoštva mogućnosti i kao takva osporavanje realnosti, nepriznavanje bilo kakvih a priori datosti i konvencijama ograđenih formi. Igra $\mathrm{i}$ humor su zapravo otpor i stvaranje i kao takve osnovne odlike autentične i originalne književnosti.

Studija Edine Murtić, u tom smislu, predstavlja vrlo važno ostvarenje, jer putem tumačenja reprezentativnih uzoraka čitavog Ćopićevog dela, obraća pažnju ne na spolajšnje činioce, ideološku zasićenost ili recepcijska ne/prihvatanja, već zapravo na osnovne kvalitete i krucijalne poetičke odlike Ćopićeve književnost na integralnom nivou. Studiju otvara poglavlje pod naslovom Književnoteorijski pristup Ćopićevom smijehu i kao takvo ovo uvodno poglavlje predstavlja veoma važan aspekt. Autorka se ovde podrobno bavi Bahtinovim konceptom karnevala, odnosno karnevalizacije. Kako Bahtin rekonstruiše kolektivno-nesvesni princip karnevala i primenjuje njegov koncept različite aspekte čovekovog života i stvaranja, on zapravo polazi od njegove subverzivnosti i teze da je to vreme apsolutne relativnosti i otklon od svih mogućih pravila i normi svakodnevnog života. Zastupajući ovu tezu, autorka napominje da je smeh, odnosno humor u Ćopićevoj prozi spasonosni otklon od najvećih stradanja, muka i patnje, da je zapravo spasonosni momenat u kome se život postavlja kao moguć i razumljiv u takvom jezivom konceptu. Podvlačeći takođe i transponovanje mitskog u doba rata i stradanja, ona ističe vrednosni aspekt Ćopićevog dela baš njegovom vezom sa najdubljom tradicijom, sa arhetipovima sveopšteg ljudskog iskustva. Dalje je studija koncipirana tako što se autorka veoma sistematično bavi njegovim opusom u književnoistorijskom kontekstu. Ona pregledno i taksativno 
navodi život Ćopićevog opusa od predratnog do poratnog perioda, njegovu sudbinu u južnoslovenskoj interliterarnoj zajednici, kao i veći deo njegovog opusa, a to je književnost za decu. Takođe, $\mathrm{s}$ otklonom književnog istoričara, navodi prilike $\mathrm{u}$ književnom kontekstu onog vremena, dozu ideološke zasićenosti, kao i prisile na istu, Ćopićevo rano odstupanje od angažovane književnosti i njegove pokušaje (uslovno rečeno) bavljenja satirom koje su ga i dovele do javnog osporavanja, prećutkivanja i, napokon, njegovog odustajanja u borbi s ideološkim avetima.

Centralni deo studije Edine Murtić predstavlja vrlo značajan i dragocen uvid u metodički pristup književnom delu narečenog pisca. Ono što je ovde neophodno podvući jeste sistematičnost i inovativnost. Ona, dakle, daje pregled mogućih metodičkih pristupa, ali posebno za svaku književnu vrstu odnosno rod kao primer. Tako je prva problemska interpretacija romana data na primeru Osme ofanzive, zatim pripovetke na primerima iz zbirke Bašta sljezove boje, a potom drame, tačnije komedije na primeru Odumiranje međeda. Posebno poglavlje predstavlja metodička interpretacija književnog lika Nikoletine Bursaća. Primeri ovakvih metodičkoh mogućnosti za istraživanje književnog teksta nezaobilazan su i dragocen priručnik za sve one koji se bave nastavom maternjeg jezika u osnovnim i srednjim školama. No, ova studija se ne može posmatrati isključivo kao metodički doprinos. Kroz sve ove interpretacije, autorka podvlači piščeve dominantne poetičke odrednice dajući na taj način jednu ukupnu, integralnu sliku njegovog opusa i njegove važnosti i umetničke autonomnosti bez obzira na književnoistorijski kontekst u kome se proučava.

Ćopić je tako, za razliku od načela vremena u kome piše, svoje likove individualizovao, psihološki iznijansirao, a humornu viziju sveta, a naročito lepotu sveta detinjstva, podigao do najvišeg stepena. Slika sveta u delima ovog autora počiva na dihotomnoj strukturi, najpre na njenim klasičnim osnovima na kome se odražava razdvojenost čovekove korporalne i duhovne egzistencije, sna i jave, idela i realnosti, zatim prošlosti i sadašnjosti, tamnih i svetlih boja i tonova, rata i mira, sela i grada. Stvarnost Ćopićevog sveta i njegovih junaka je tako sačinjena iz protivurečnosti koje pokušavaju da se prevaziđu i da se dođe do ravni spokojstva i lepote, onog istinski estetski relevantnog što jeste jedna od

Stoga se može zaključiti da Umjetnost pripovedanja Branka Ćopića predstavlja jednu vrlo važnu i sveobuhvatnu studiju, ali i priručnik metodičke provenijencije. Može se tako čitati na različite načine, ali, čini se, da je najvažnije podvući da je vrednost ovog poduhvata što se takođe može pročitati i kao apologija jednom kvalitetnom piscu i originalnom književnom tekstu koji je oblikovao unutrašnji svet mnogih generacija, a kroz svoju predanu čitalačku publiku čini to i danas. 